\title{
SURAT KETERANGAN
}

Nomor: 01/A/IS/FISIP UMRAH/2019

Yang bertanda tangan di bawah ini:

Nama

: Irman, SH., MH

NIDN

: 0025128801

Jabatan

: Editor in Chief

Instansi

: Program Studi llmu Hukum FISIP UMRAH

Menyatakan bahwa artikel yang dibuat oleh:

Nama

: Novita Sri Wulandari

Judul

: Penegakan Wibawa Pengadilan Terkait Adanya Perilaku Penghinaan Terhadap Peradilan (Contempt of Court) Ditinjau Dari Hukum Administrasi

Telah direview dan dinyatakan layak untuk diterbitkan pada Jurnal Selat Volume 7 Nomor 1 Oktober 2019.

Demikian surat keterangan ini dibuat agar dapat dipergunakan sebagaimana mestinya.
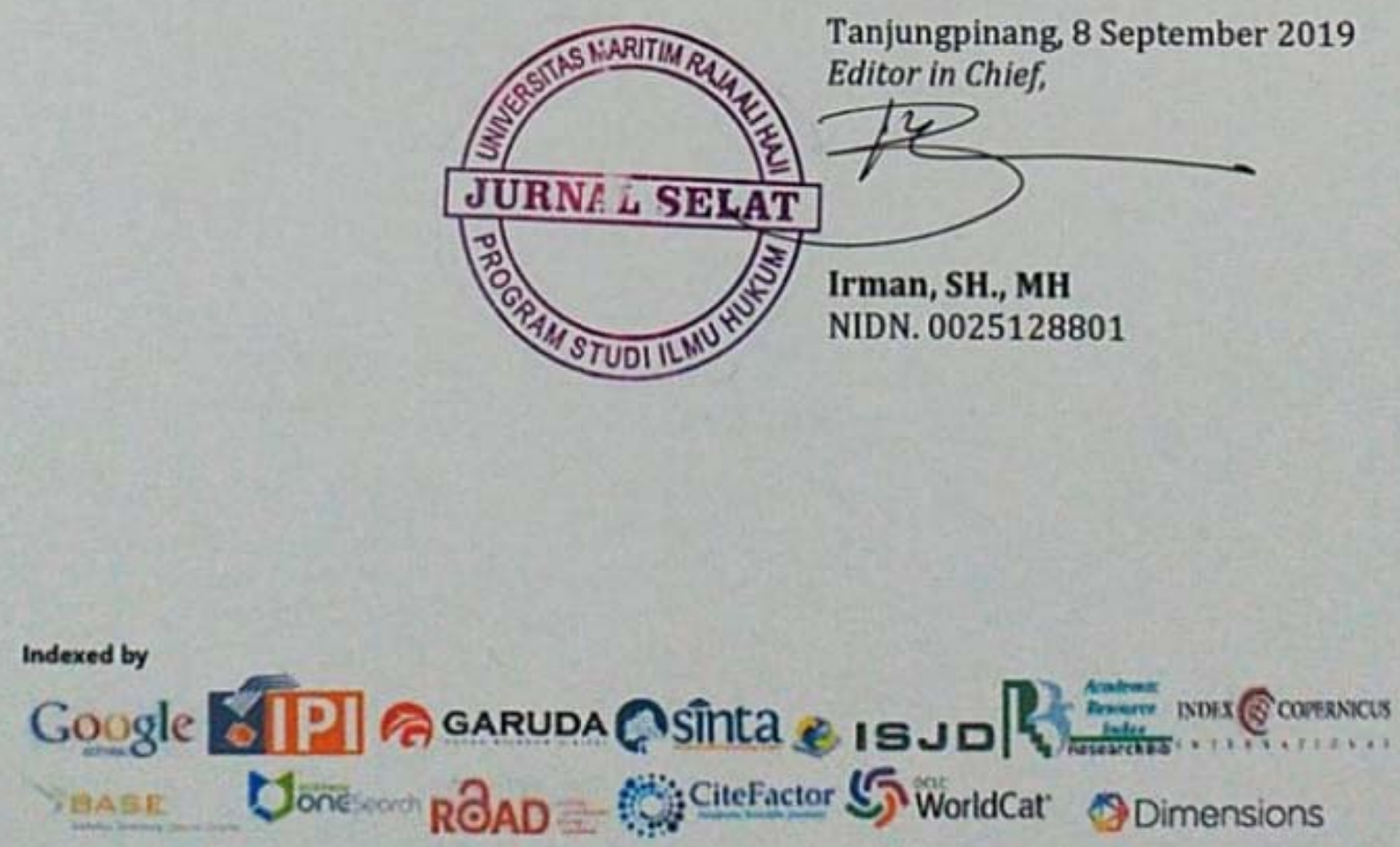


\title{
PENEGAKAN WIBAWA PENGADILAN TERKAIT ADANYA PERILAKU PENGHINAAN TERHADAP PERADILAN (CONTEMPT OF COURT) DITINJAU DARI HUKUM ADMINISTRASI
}

\author{
Novita Sri Wulandari \\ Program Studi Magister Kenotariataan Universitas Surabaya \\ Jalan Raya Kalirungkut, Surabaya, 60293 \\ No. Hp: 081340709540 \\ Email: Novitasri06@gmail.com
}

\begin{abstract}
Contempt of Court especially of the Indonesian Court is increasingly worrisome, in addition to the increasing number of humiliating cases, the insulting acts are also getting worse by the fact that the act of humiliation is not only limited to verbal actions by issuing dirty and inappropriate words but is worse than that, the act of contempt of court by the irresponsible persons even to the point of damaging the property of the Court, also to the danger of life, especially the Panel of Judges in the Court. Apart from that, the act of contempt of court also certainly raises anxiety and concern in the community, where people who are trying to find the truth and justice of their problems will become afraid and distrustful of the credibility of the court which can easily get insulted from public.
\end{abstract}

Keywords: Contempt of Court, Panel of Judges, Justice.

\begin{abstract}
Abstrak
Penghinaan terhadap Pengadilan atau yang lebih dikenal dengan sebutan Contempt of Court, yang dilakukan terhadap Pengadilan, terutama terhadap pengadilan di Indonesia saat ini, semakin hari semakin mengkhawatirkan, dimana jumlah kasus penghinaan yang dilakukan terhadap pengadilan semakin meningkat, dan hal ini semakin diperburuk dengan fakta bahwa tindakan penghinaan yang dilakukan tersebut bukan hanya dilakukan sebatas pada tindakan verbal dengan mengeluarkan kata-kata kotor dan tidak pantas yang ditujukan kepada pengadilan, namun lebih buruk daripada itu, tindakan penghinaan terhadap pengadilan yang dilakukan oleh oknum-oknum yang tidak bertanggung jawab ini bahkan hingga mengakibatkan rusaknya properti Pengadilan, juga sampai membahayakan keselamatan jiwa khususnya Majelis Hakim di Pengadilan. Selain daripada itu, tindakan penghinaan terhadap pengadilan ini juga tentunya menimbulkan keresahan dan kekhawatiran dalam masyarakat, dimana masyarakat yang sedang berusaha mencari kebenaran dan keadilan dari masalah yang dihadapinya akan menjadi takut dan tidak percaya dengan kredibilitas dari pengadilan yang dengan mudahnya mendapatkan penghinaan dari masyarakat secara umum.
\end{abstract}

Kata Kunci : Penghinaan Pengadilan, Majelis Hakim, Peradilan. 